\title{
Touch Feeling Evaluation of Sun Visor for Automobiles
}

\author{
YAMASHITA Yoshihiro, ${ }^{\text {a, }}$, KUMAMOTO Shuji ${ }^{\mathrm{a}}$, IWAMOTO Katsutoshi ${ }^{\mathrm{b}}$, \\ ISHIKURA Kunihiko ${ }^{b}$, MIYAKE Hajime ${ }^{c}$ \\ ${ }^{a}$ The University of Shiga Prefecture, 2500 Hassaka Hikone, Shiga 522-8533, Japan \\ ${ }^{\mathrm{b}}$ Kyowasangyo Co. Ltd., 2-19-6 Jinnakacho Toyota, Aichi 471-0079, Japan \\ ${ }^{\mathrm{c}}$ North Eastern Industrial Research Center of Shiga Prefecture, Nagahama, Shga 526-0024, Japan
}

Received 7 April 2008; accepted for publication 14 July 2008

\begin{abstract}
A sun visor has been used only for the purpose of interrupting direct sunshine. Investigation, therefore, has not been made to be on the feeling of touch of the sun visor. In this study, the feeling of touch of sun visor installed in the present automobile was investigated. To clarify the relation between the sense of touch and the mechanical and physical quantity of the sun visor, prototype products of the sun visor of the same shape were made. Surface characteristics and cold feel characteristic of materials were measured by the KES system. In addition, we investigated the relation between the surface property and the sense of touch of various materials. The correlation between favorability and WC, RC, SMD was high on the sun visor prototype. As a result, it was clarified that materials whose surfaces were very smooth and soft were favorable. Those materials consist of leather and moquette. Conversely, the material sensed hard was not favorable. The relation between the mechanical and the physical properties of various materials, and the favorability was able to be approximated by the equation (1).
\end{abstract}

Favorability $=2.482+0.02791 L C+0.293 W C-0.264 R C$

$+0.0688 M I U-0.0966 M M D+0.0253 S M D-0.0288 q \max$

Key Words: Sun visor, KES system, Hand evaluation, Feeling of touch

\author{
自動車用サンバイザーの触感評価 \\ 山下義裕 ${ }^{\mathrm{a},}{ }^{\mathrm{k}}$ ，熊本修二 ${ }^{\mathrm{a}}$ ，岩本勝敏 ${ }^{\mathrm{b}}$, 石倉邦彦 ${ }^{\mathrm{b}}$, 三宅 肇 ${ }^{\mathrm{c}}$ \\ ${ }^{a}$ 滋賀県立大学工学部, ${ }^{b}$ 共和産業株式会社, ${ }^{c}$ 滋賀県東北部工業技術センター
}

\section{1. 緒 言}

自動車の内装品のひとつにサンバイザーがある。これは夕 日などの太陽光が直接運転者や助手席の人に当たるのを避け る目的で取り付けられている. サンバイザーの中でバスやト ラックなどの大型車ではない自家用自動車の場合，サンバイ ザーの表皮材には天井の内装材と同一もしくはよく似た素材 が用いられている[1-3]. 自動車用シート表皮材の風合いに 関しては西松らの報告がある $[4,5]$. ところで天井内装材な どに比べてサンバイザーは利用のために人が触る機会が非常 に多い.これまでサンバイザーは直射日光をさえぎることの みが重要視され, その触感についてはほとんど調查・研究が
されていない.このサンバイザーは自動車内装品のひとつで あるが, それに求められている風合いがシート表皮材や天井 などの内装品と同じであるかどうかはわからない. 今後はサ ンバイザーに従来の化粧用鏡やライトだけでなく，さらに新 しい機能を付与しようとする場合にサンバイザー自身に求め られている触感を知ることは非常に重要である。本研究では まず現在の自動車に取り付けられているサンバイザーの好ま れる触感を調査した。 それをもとにサンバイザーとしての触 感の好みがサンバイザーの形状やその内部のクッション材の 特性に左右されないように, 形状の同じサンバイザーの型枠 に実際のサンバイザーの表皮材を挟み込んで固定したサンバ イザー試作品を作成して再度調査を実施した。さらにこれら

* 連絡先：滋賀県立大学工学部材料科学科 522-8533 滋賀県彦根市八坂町 2500

E-mail: yamashit@mat.usp.ac.jp, Tel: +81-749-28-8582,Fax: +81-749-28-8582 
から得られた触感の評価がサンバイザーに特有な傾向である のか，それとも一般的かどうかを確認するために，さまざま な表面特性をもつ材料についても触感を評価してもらうこと で人に好まれる触感の特性を明らかにすることを試みた。

\section{2. 実 験}

\section{1 表面特性の測定}

表面特性を知るために圧縮試験(KESハンディー圧縮試験機, カトーテック(株)）と表面試験（KES-SE，カトーテック(株)) を行った．測定条件はいずれも標準条件である．測定項目の 略記号とその特性值ならびに単位は以下のと扔りである. $L C$ (圧縮荷重一圧縮ひずみ曲線の直線性, 単位なし), $W C$ (圧縮仕事量, $\left.\mathrm{gf} \cdot \mathrm{cm} / \mathrm{cm}^{2}\right), R C$ (圧縮レジリエンス, \%), $M I U$ (表面平均摩擦係数, 単位なし), $M M D$ (摩擦係数の平 均偏差, 単位なし), $S M D$ (平均粗さ, $\mu \mathrm{m}$ ). しかし表面がと げとげしく硬い材料や平板に穴の開いた金属板などでは表面 粗さ $S M D$ 值が大きくばらついた。その原因は粗さセンサー がワイヤーリングであるためにワイヤーの幅より小さい穴の 部分に入り込むことができなかったり，凹凸の高さが $0.2 \mathrm{~mm}$ 程度のとげとげした表面が無数にある材料ではその上を粗さ センサーのワイヤーリングがなぞってしまうため凹凸を正し く検出できないことによる。すなわち指で触った場合にはチ クチク感や細かい穴の凹凸を感知できるが $S M D$ 值にはそれ が反映されていない.これは粗さセンサーがもともと織物の 表面測定のために開発されたことによる. そこでワイヤーリン グによる粗さ測定と変位レーザー (LB-040, キーエンス (株)) による粗さ測定を Table 3に示したすべてのサンプルで併用 して行なった。ワイヤーリング測定では $10 \mathrm{gf}$ の荷重を負荷 した状態で行なわれるがレーザー測定の場合は無荷重であ る. そのため $S M D$ 值とレーザー測定による表面粗さの平均 值は一致しない.しかし $S M D$ 值とレーザー測定による表面 粗さの相関倸数は 0.82 (有意水準 $5 \%$ ) であった。 そのため 両者の間に 1 次式で記述される線形関係が成り立つと仮定す るとレーザー測定による粗さを $S M D$ 值に置き換えることが 可能である．そこで $S M D$ 值とレーザーによる表面粗さ值の ずれの大きいNo.26, No.27, No.33の三つの試料についてのみ KES-SEのワイヤーリングセンサーで得た SMD 值ではなくレー ザー測定から換算した表面粗さ值を $S M D$ 值として用いた。

\section{2 好感度の評価}

好感度の評価は 21 歳から 58 歳までの男女 27 人（男 17 人， 女 10 人）で行った。市販のサンバイザーについては表面を 軽く触って「なでた場合」と取り出すときのようにつかんで 「押した場合」の触感を 3 段階（はい=そう思う，いいえ= そう思わない, どちらでもない）で調查した。表面をなでた 場合はその触感が「暖かい」，「べたべたする」（ぬれた感触， 粘着性のある感触), 「滑らか」,「軟らかい」の4 項目につい て行なった。これらの表現語は川端[6]による風合いの形容
詞を参照した。一方押した場合は「硬い」，「底付きする」 （市販のサンバイザーは表皮材の下にスポンジなどのクッショ ン材があり，さらにその下には形状を保持するための硬い材 質がある. スポンジなどの厚みは車種や自動車のグレードに よりまちまちである。底付きする感触とはクッション部分が 薄く押したときにすぐに保持材まで達して硬いと感じること を指す)，「べこべこする」(表皮材，クッション材，保持材 などが硬くて薄い場合には押し込んだ時に大きく変形する 様)，「ぐにゃりとする」(表皮材，クッション材，保持材な どの粘性が大きい場合の変形の様）である．押した場合の表 現も川端の表現語[6]とサンバイザーに特有な特性を考虑し て選定した。

サンバイザー試作品とさまざまな材料については好きか嫌 いかについて5段階で評価（はい，どちらかといえばはい， どちらでもない, どちらかといえばいいえ，いいえ）しても らった。サンバイザー試作品についてはサンバイザーとして 好きな触感か嫌いな触感かを尋ねた。さまざまな材料につい てはサンバイザーに関係なく単純にその触感が好きな触感か 嫌いな触感かを尋ねた。

\section{3 市販のサンバイザー}

市販されているサンバイザーは実際の自動車に取り付けら れる製品であり，サイズができるだけ同じで材質や価格の異 なる商品を14種類選んだ（Table 1)。これらのサンバイザー の中で代表的な製品の写真を Fig. 1 に示す. 市販のサンバイ ザーは形状がさまざまでまた全体が歪曲形状をしているため にKESによる力学量や物理量を計測は困難だった.

\section{4 サンバイザー試作品}

市販のサンバイザーでは触感評価が形状や色，デザインな どの心理的な要因に左右される可能性がある。そこでサンバ イザーの表皮材のみをサンバイザーの形をした型枠に挟み込 んで固定し形状や表皮材内部のスポンジの硬度などを一定に したサンバイザーを14種類試作しKESによる力学量や物理 量を計測した. (Table 2).

\section{5 異なる触感を持つさまざまな材料}

サンバイザーに使われる表皮材としては織物，人工皮革， ポリ塩化ビニル（PVC）などが多いが，サンバイザーとさま ざまな材料で好まれる触感が同じかどうか，さらに人に好ま れる触感をもつ材料を探索するために，Table 3 に示すよう な材料を 38 種類選び力学量や物理量を計測した.

\section{6 相関係数の算出}

相関係数と多変量解析はEXCEL（マイクロソフト（株)) とSPSS (エス・ピー・エス・エス (株) ) の 2 種類のソフト を用いた。 
Table 1 Characteristic and the favorability of sun visor for product.

\begin{tabular}{|c|c|c|c|}
\hline Sample No. & $\begin{array}{l}\text { Cover material and } \\
\text { characteristic of sun visor for } \\
\text { product }\end{array}$ & $\begin{array}{l}\text { Evaluation of } \\
\text { favorability of "Pat " } \\
\text { and "Push" } \\
\text { (Evaluation is so good } \\
\text { that a number is } \\
\text { small) }\end{array}$ & $\begin{array}{l}\text { Total evaluation as } \\
\text { sense of touch of } \\
\text { sun visor (Evaluation } \\
\text { is so good that a } \\
\text { number is small) }\end{array}$ \\
\hline 1 & $\begin{array}{l}\text { Moquette. Internal sponge is } \\
\text { soft. Under the moquette and the } \\
\text { sponge, there is a hard core } \\
\text { material. Thick sun visor. }\end{array}$ & 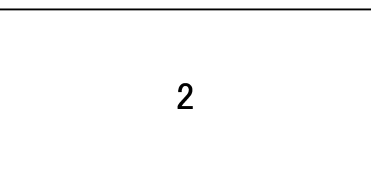 & 2 \\
\hline 2 & $\begin{array}{l}\text { Soft moquette. The surface is } \\
\text { very smooth. }\end{array}$ & 3 & 3 \\
\hline 3 & $\begin{array}{l}\text { Moquette (front side). Fabric } \\
\text { (back side). Thin and soft sun } \\
\text { visor. }\end{array}$ & 4 & 4 \\
\hline 4 & $\begin{array}{l}\text { Soft artificial leather. There } \\
\text { is feeling of luxury in the } \\
\text { whole. }\end{array}$ & 1 & 1 \\
\hline 5 & $\begin{array}{l}\text { Soft PVC(Polyvinyl chloride). } \\
\text { There are a skid resistance and } \\
\text { slipping on the surface. }\end{array}$ & 7 & 8 \\
\hline 6 & $\begin{array}{l}\text { The surface is a moquette } \\
\text { pattern textile that consists } \\
\text { of a short fluff. }\end{array}$ & 5 & 6 \\
\hline 7 & $\begin{array}{l}\text { Plastic resin blow cast. It is } \\
\text { hard to the whole. }\end{array}$ & 13 & 11 \\
\hline 8 & Soft PVC. & 12 & 9 \\
\hline 9 & $\begin{array}{l}\text { The surface consists of soft PVC } \\
\text { with the crimp. }\end{array}$ & 8 & 7 \\
\hline 10 & $\begin{array}{l}\text { PVC to which design is applied. } \\
\text { The surface is smooth. }\end{array}$ & 11 & 12 \\
\hline 11 & $\begin{array}{l}\text { It is very softness in the } \\
\text { whole. }\end{array}$ & 6 & 5 \\
\hline 12 & $\begin{array}{l}\text { It is the hardest in all product } \\
\text { sun visors. }\end{array}$ & 14 & 14 \\
\hline 13 & $\begin{array}{l}\text { PVC. It is smooth in the whole } \\
\text { though there is slightly a skid } \\
\text { resistance. }\end{array}$ & 10 & 13 \\
\hline 14 & PVC. Thick sun visor. & 9 & 10 \\
\hline
\end{tabular}



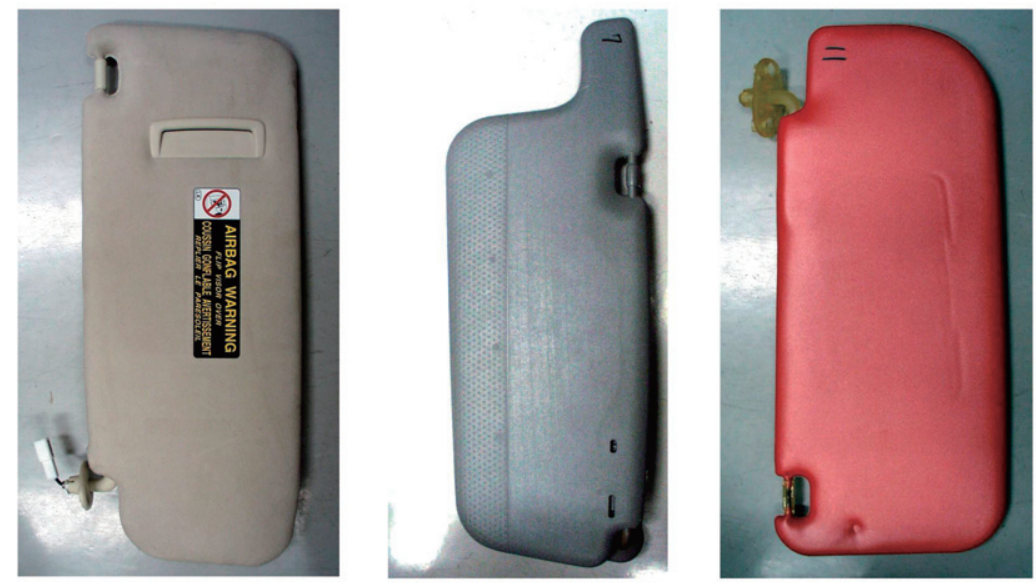

Sample 4(Artificial leather) Sample 7(Blow molding) Sample 11(Polyvinyl chloride,PVC)

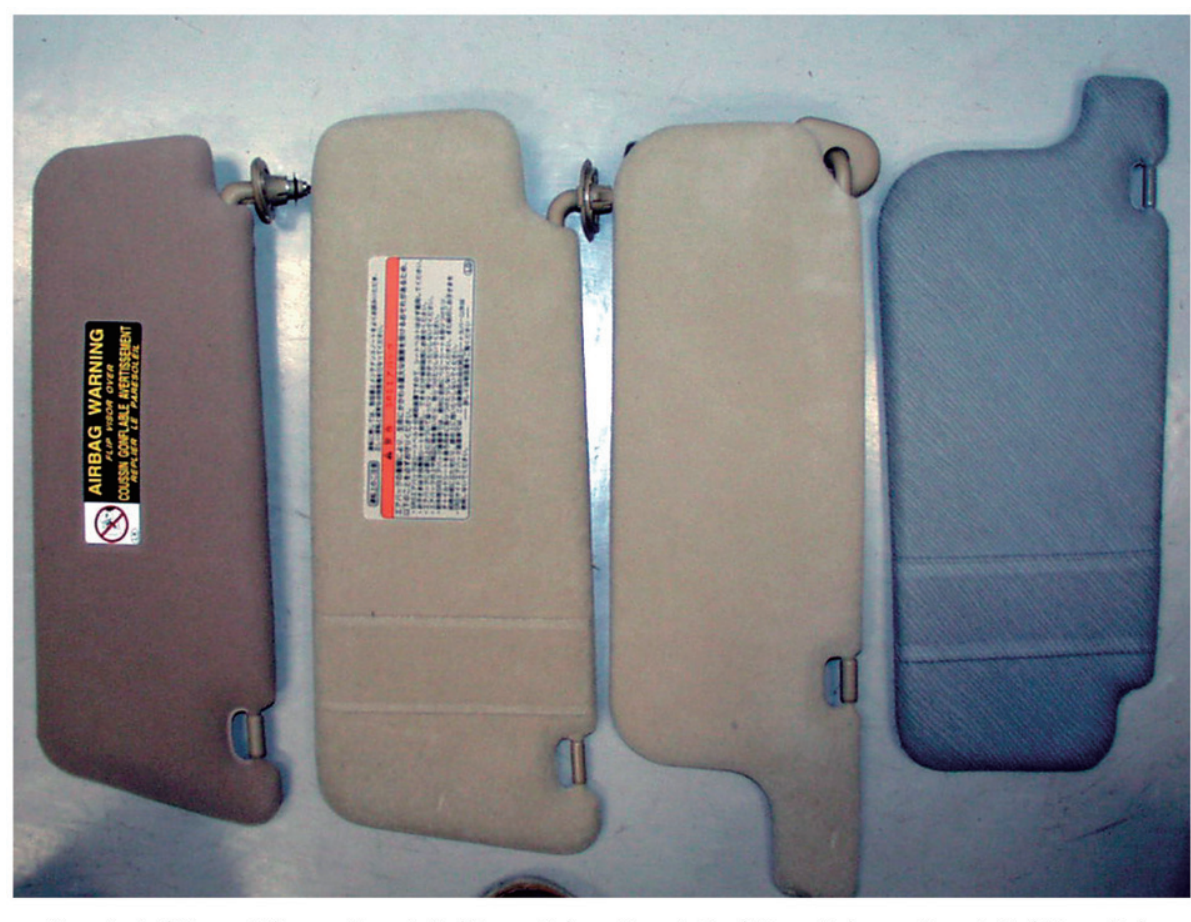

Sample 1 (Moquette) Sample2 (Moquette) Sample3 $\quad$ (Moquette) Sample6 (Moquette)

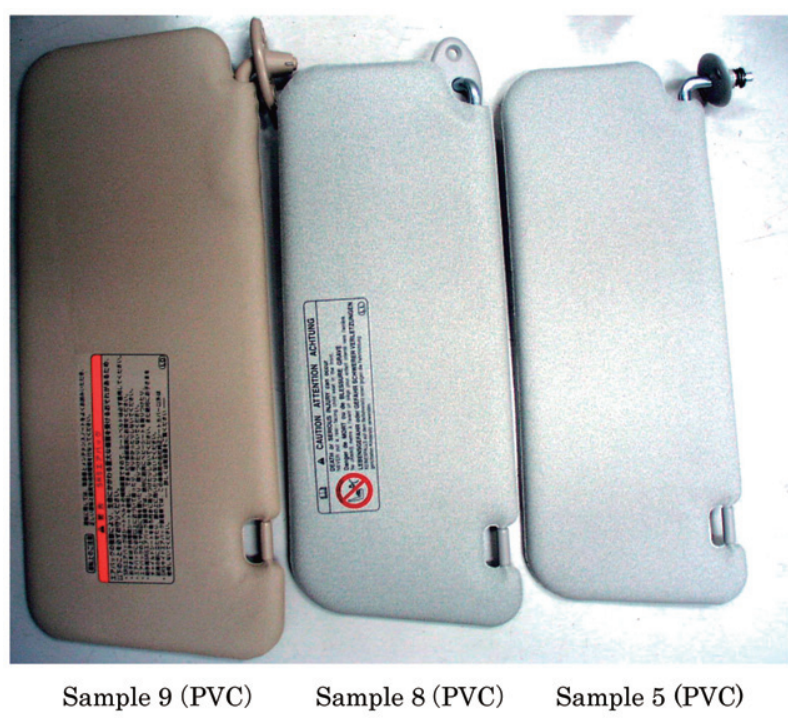

Fig. 1 Some photographs in the commercial sun visor shown in Table 1. The inside of a parenthesis is explanation of the kind of cover material or the molding method. 
Table 2 Sun visor prototype (cover material is inserted in the common sun visor mould).

\begin{tabular}{|c|c|c|c|c|c|c|c|c|}
\hline $\begin{array}{c}\text { Features of the prototype } \\
\text { sun visor }\end{array}$ & $\begin{array}{c}\text { Evaluation } \\
\text { of } \\
\text { favorability } \\
\text { as sun visor }\end{array}$ & $\begin{array}{c}\text { WC } \\
(\mathrm{gf} \cdot \\
\left.\mathrm{cm} / \mathrm{cm}^{2}\right)\end{array}$ & $\begin{array}{c}\text { LC } \\
(-)\end{array}$ & $\begin{array}{c}\text { RC } \\
(\%)\end{array}$ & $\begin{array}{c}\text { MIU } \\
(-)\end{array}$ & $\begin{array}{c}\text { MMD } \\
(-)\end{array}$ & $\begin{array}{c}\text { SMD } \\
(\mu \mathrm{m})\end{array}$ & $\begin{array}{c}\text { qmax } \\
\left(\mathrm{Wm}^{-2}\right)\end{array}$ \\
\hline $\begin{array}{c}\text { Hard resin plate with } \\
\text { surface wrinkle }\end{array}$ & 3.1 & 0.34 & 0.15 & 73 & 0.42 & 130 & 1.3 & 0.27 \\
\hline Textile with slipping & 3.5 & 0.41 & 0.50 & 32 & 0.42 & 53 & 0.6 & 0.45 \\
\hline $\begin{array}{c}\text { The resin board with which } \\
\text { one side consists of mirrors }\end{array}$ & 3.8 & 0.24 & 0.09 & 86 & 0.23 & 460 & 0.6 & 0.30 \\
\hline Leather & 4.1 & 0.32 & 0.37 & 51 & 0.47 & 180 & 1.3 & 0.40 \\
\hline Textile & 3.4 & 0.25 & 0.21 & 53 & 0.51 & 105 & 2.9 & 0.42 \\
\hline Rough textile & 2.9 & 0.38 & 0.31 & 65 & 0.36 & 360 & 23.0 & 0.28 \\
\hline $\begin{array}{c}\text { Resin plate (plain weave } \\
\text { pattern is printed) }\end{array}$ & 3.2 & 0.61 & 0.04 & 93 & 0.17 & 380 & 0.6 & 0.48 \\
\hline PVC & 3.5 & 0.33 & 0.05 & 65 & 0.35 & 92 & 0.4 & 0.53 \\
\hline $\begin{array}{c}\text { Textile with wrinkle } \\
\text { Metal plate (there are small } \\
\text { circular holes) }\end{array}$ & 2.5 & 0.47 & 0.32 & 67 & 0.58 & 180 & 2.6 & 0.38 \\
\hline $\begin{array}{c}\text { Metal plate (there are large } \\
\text { circular holes) }\end{array}$ & 3.4 & 0.71 & 0.23 & 95 & 0.15 & 185 & 2.5 & 1.10 \\
\hline Translucid resin board & 2.8 & 0.41 & 0.18 & 67 & 0.32 & 180 & 2.8 & 0.31 \\
\hline $\begin{array}{c}\text { Resin board } \\
\text { Buckskin }\end{array}$ & 2.7 & 0.65 & 0.09 & 91 & 0.18 & 350 & 0.7 & 0.45 \\
\hline $\begin{array}{c}\text { (two kinds of the metal plate } \\
\text { are excluded) }\end{array}$ & 3.4 & 0.38 & 0.15 & 43 & 0.45 & 130 & 1.3 & 0.35 \\
\hline $\begin{array}{c}\text { Correlation coefficient of } \\
\text { favorability and mechanical } \\
\text { /physical quantity } \\
\text { (all prototype products) }\end{array}$ & -0.281 & 0.085 & -0.206 & 0.138 & -0.082 & -0.381 & 0.185 \\
\hline $\begin{array}{c}\text { Correlation coefficient of } \\
\text { favorability and mechanical }\end{array}$ & & -0.593 & 0.099 & -0.341 & 0.036 & -0.107 & -0.444 & 0.176 \\
\hline
\end{tabular}

Table 3 Relation between mechanical / physical quantity and favorability of various materials.

\begin{tabular}{|c|c|c|c|c|c|c|c|c|c|}
\hline $\begin{array}{c}\text { sample } \\
\text { No. }\end{array}$ & Feature of material & $\begin{array}{c}\text { Evaluation } \\
\text { of } \\
\text { favorability } \\
\text { as material }\end{array}$ & $\begin{array}{c}\text { LC } \\
(-)\end{array}$ & $\begin{array}{c}\text { WC } \\
(\mathrm{gf} \cdot \\
\left.\mathrm{cm} / \mathrm{cm}^{2}\right)\end{array}$ & $\begin{array}{c}\text { RC } \\
(\%)\end{array}$ & $\begin{array}{c}\text { MIU } \\
(-)\end{array}$ & $\begin{array}{c}\text { MID } \\
(-)\end{array}$ & $\begin{array}{c}\text { SMD } \\
(\mu \mathrm{m})\end{array}$ & $\begin{array}{c}\text { qmax } \\
\left(\mathrm{Wm}^{-2}\right)\end{array}$ \\
\hline 1 & Textile A (with printed) & 3.0 & 0.42 & 0.31 & 63.04 & 0.35 & 368 & 20.50 & 0.23 \\
\hline 2 & Leather A (thin) & 3.0 & 0.35 & 0.15 & 46.34 & 0.40 & 121 & 1.27 & 0.43 \\
\hline 3 & Leather B & 3.1 & 0.37 & 0.21 & 64.63 & 0.28 & 97 & 0.68 & 0.51 \\
\hline 4 & Leather C & 3.0 & 0.33 & 0.36 & 49.70 & 0.18 & 119 & 1.35 & 0.39 \\
\hline 5 & Leather D & 3.9 & 0.39 & 0.46 & 37.55 & 0.38 & 51 & 0.62 & 0.43 \\
\hline 6 & Leather E & 3.0 & 0.45 & 0.21 & 48.26 & 0.37 & 196 & 1.42 & 0.41 \\
\hline 7 & Buckskin A (soft) & 5.0 & 0.46 & 0.50 & 45.12 & 0.38 & 82 & 1.11 & 0.42 \\
\hline 8 & Buckskin B (hard) & 3.0 & 0.37 & 0.33 & 38.38 & 0.35 & 124 & 1.62 & 0.40 \\
\hline 9 & Textile B (thin) & 3.0 & 0.34 & 0.13 & 49.24 & 0.26 & 384 & 3.63 & 0.39 \\
\hline
\end{tabular}




\begin{tabular}{|c|c|c|c|c|c|c|c|c|c|}
\hline 10 & Textile C & 2.6 & 0.51 & 0.34 & 58.57 & 0.30 & 240 & 15.76 & 0.23 \\
\hline 11 & Leather F (thick) & 3.0 & 0.48 & 1.76 & 75.59 & 0.17 & 90 & 0.39 & 0.51 \\
\hline 12 & Knitting & 3.0 & 0.39 & 0.23 & 68.61 & 0.16 & 152 & 2.67 & 0.21 \\
\hline 13 & Textile C (soft) & 4.0 & 0.33 & 0.38 & 52.53 & 0.21 & 64 & 2.62 & 0.35 \\
\hline 14 & Textile D (gauze) & 2.6 & 0.22 & 0.02 & 84.90 & 0.14 & 87 & 2.37 & 0.49 \\
\hline 15 & Textile E (jeans) & 3.4 & 0.41 & 0.15 & 52.05 & 0.17 & 101 & 2.86 & 0.44 \\
\hline 16 & Textile F (rough plain weave) & 3.0 & 0.34 & 0.34 & 52.81 & 0.22 & 277 & 3.38 & 0.33 \\
\hline 17 & Textile G (coating) & 2.0 & 0.40 & 0.07 & 72.74 & 0.20 & 74 & 0.53 & 0.54 \\
\hline 18 & Leather G (soft) & 3.0 & 0.35 & 0.62 & 28.71 & 0.42 & 73 & 0.95 & 0.40 \\
\hline 19 & Leather $\mathrm{H}$ (hard) & 2.0 & 0.34 & 0.23 & 46.43 & 0.27 & 55 & 3.41 & 0.34 \\
\hline 20 & Sponge & 3.3 & 0.24 & 2.53 & 56.56 & 0.40 & 102 & 3.67 & 0.15 \\
\hline 21 & $\mathrm{PVC}$ & 2.0 & 0.42 & 0.05 & 74.02 & 0.25 & 81 & 0.38 & 0.73 \\
\hline 22 & Plywood (thin) & 2.0 & 0.60 & 0.08 & 84.44 & 0.19 & 468 & 0.57 & 0.62 \\
\hline 23 & Cork board & 2.0 & 0.66 & 0.16 & 75.76 & 0.32 & 165 & 2.07 & 0.21 \\
\hline 24 & Wooden board A & 2.0 & 0.79 & 0.05 & 83.22 & 0.17 & 347 & 0.57 & 0.64 \\
\hline 25 & Wooden board B & 2.0 & 0.68 & 0.08 & 73.48 & 0.12 & 300 & 1.39 & 0.48 \\
\hline 26 & $\begin{array}{c}\text { Metal plate A } \\
\text { (round-hole mesh) }\end{array}$ & 2.0 & 0.75 & 0.11 & 100.00 & 0.16 & 334 & 16.07 & 0.80 \\
\hline 27 & $\begin{array}{c}\text { Metal plate B } \\
\text { (small round-hole mesh) }\end{array}$ & 2.0 & 0.70 & 0.28 & 97.24 & 0.13 & 202 & 2.10 & 1.28 \\
\hline 28 & Glass plate A & 2.0 & 0.81 & 0.06 & 100.00 & 0.16 & 120 & 1.80 & 1.18 \\
\hline 29 & Glass plate B & 2.0 & 0.40 & 0.01 & 100.00 & 0.26 & 259 & 10.30 & 0.91 \\
\hline 30 & $\begin{array}{c}\text { Glass plate C } \\
\text { (convexo concave pattern) }\end{array}$ & 1.6 & 0.67 & 0.00 & 100.00 & 0.15 & 266 & 19.50 & 0.99 \\
\hline 31 & Glass plate D (pattern) & 2.0 & 0.73 & 0.01 & 100.00 & 0.17 & 595 & 20.37 & 0.69 \\
\hline 32 & Glass plate E & 2.0 & 0.47 & 0.01 & 100.00 & 0.14 & 176 & 11.62 & 1.05 \\
\hline 33 & Brick A (rough surface) & 1.0 & 0.51 & 0.06 & 69.74 & 0.24 & 789 & 1.57 & 0.66 \\
\hline 34 & Brick B & 1.4 & 0.85 & 0.01 & 96.55 & 0.19 & 392 & 2. 19 & 1.06 \\
\hline 35 & Soft stone & 1.0 & 0.22 & 0.00 & 100.00 & 0.26 & 158 & 1.70 & 0.94 \\
\hline 36 & Granite & 2.0 & 0.29 & 0.01 & 100.00 & 0.09 & 95 & 0.23 & 1.30 \\
\hline 37 & Aluminum foil & 1.6 & 0.80 & 0.13 & 57.32 & 0.16 & 40 & 8.17 & 0.80 \\
\hline 38 & Balsa light plate & 2.0 & 0.41 & 0.12 & 74.05 & 0.18 & 36 & 1.32 & 0.22 \\
\hline & $\begin{array}{c}\text { Correlation coefficient } \\
\text { of favorability and } \\
\text { mechanical /physical } \\
\text { quantity }\end{array}$ & & -0.38 & 0.68 & -0.68 & 0.49 & -0.36 & -0.14 & -0.56 \\
\hline
\end{tabular}

\section{3. 結果と考察}

\section{1 市販のサンバイザー}

市販のサンバイザー14種類について触感の官能評価を行っ た結果を Table 1 に示す. 母集団の人数が少ないので, 男女 や年齢を区別せずに全体として好きなサンバイザーの特徵を 探ることに主眼を置いた。Table 1にはサンバイザーとして 好ましい触感の総合評価と好きな触感（なでた場合と押した 場合の好感度の合計）の評価を示した。総合評価はサンバイ
ザーに用いられている表皮材料の触感を総合して優れている かどうかの判定であり，好きな触感はサンバイザーをなでた 場合と押した場合の喏好を尋ねている。総合判断と好きな触 感は必ずしも一致するものではないが，本研究では上位では ほぼ同じ結果になったが下位では幾分ばらつきが生じた。こ れはNo.8やNo.9の触感は良くないが総合判断ではそれがサ ンバイザーとしてなじみのある PVC素材のサンバイザーであ るためにサンバイザーとしては評価されたことなどが考えら れる。したがってこの総合評価には触感としての総合評価以 外のサンバイザーとして利用したときに優れているかどうか 
の評価も幾分含まれていると推測される.No.4は革のタッチ を持っておりなでた場合も押した場合も総合評価も商品の中 では最も優れていた。この材質は人工皮革であり，見た目に も高級感がある.その次によい評価のNo.1 と No.2 は自動車 用表皮シート素材と似たモケットの触感をもち，表面の毛羽 をなでた感じが好まれていると思われる．No.3は短い毛羽で あるのに対してNo.1 やNo.2の方が毛羽は長い。毛羽の長い 方がなでた時の触感がよいためにNo.3よりもNo.1やNo.2の 方が高い評価になったと推察される。No.6はモケットではな く素材が不織布であり毛羽がないので表面をなでた時，軟ら かさにそしいために評価が下がっていると思われる．No.11 はPVC素材であるがこれまでのサンプルと異なり，押し达 んだ時の感触が粘土のような高い粘性の感触であり，押した 時の評価は高い。また押し込んだ時に底付きがなくサンバイ ザー商品の中では特徵的である。No.5, No.8，No.9もいずれ も PVC素材である。これらの表皮はNo.11 と大差はないが押 し込んだ時に硬いのでそれも評価に影響しているようであ る.No.5は表面がざらざらしておりなでた時の評価は低いに

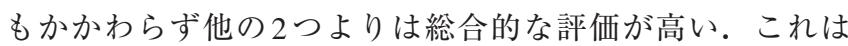
No.5が小型でサンバイザーとして取り扱いやすいと判断され たために総合評価が高くなったと考えられる。これら3つは いずれも押し込んだ時の感触は似ている．No.10，No.13は同 じような表皮素材でありなでた時と押した時の感触もほぼ同

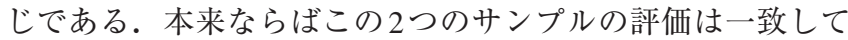
もよいはずであるが評価は異なった。その原因としてはいず れも表皮にデザインが施されておりそれが影響した可能性は 否定できない。またサイズが他のものよりもかなり小さい. これらはNo.5よりもサイズが小さいのでサンバイザーとし ての機能性に劣ると判断され評価が下がったとも考えられ る. No.7 は樹脂成型品でありサンバイザー商品としては低コ スト化のために重要な商品と思われるが評価はかなり低かっ た。押した時の感触はスポンジとは違い硬いが内部は中空で あるのでべこべこする．またなでた時の感触も樹脂板と代わ り映えしないことが原因と思われる。さらに全体的に安っぽ いというイメージも評価を下げた原因であろう。No.12はサ ンバイザー商品の中では押した時に一番硬くそのために評価 が最も低い.No.12の表皮素材はNo.14 と同等であるがなで た時もやはり評価は低い。すなわち押したときの悪いイメー ジがどうしてもなでた時にも影響していると思われる。逆に No.14 は表皮の内側のスポンジ部分がNo.12より軟らかいの でNo.14の方が評価がよくなった。従って押した時の触感は なでた時にも影響する。これはなでる時もある程度の力で押 していることも影響しているためである.

すなわち好まれる市販のサンバイザーとしては表面が滑ら かな革のような触感で押し达んだ時に底付きがなく軟らかい 感触のものが良いようである。言い換えると全般的に軟らか い表皮素材で表面が滑らかもしくはつるつると感じるものが 好まれる傾向がある，逆に好まれないサンバイザーの夕イプ は硬い素材でできたものである．市販のサンバイザーでは表 皮材だけでなく内部のスポンジの触感も評価に大きく影響す ることがわかったが，この点については今後の課題である。

\section{2 サンバイザー試作品}

市販用のサンバイザーではその形状や表面だけではなく， 押し込んだ時の内部のスポンジの硬さも触感の評価に影響し ている，そのため，形状を同じにするために，サンバイザー の形状をした型枠にさまざまな触感をもつ材料を挟み込んで 評価をした。Table 2 に，それぞれの素材の好感度の評価 と力学量や物理量を示す。すべてのサンバイザー試作品を対 象とした力学量・物理量と好感度評価の相関は弱かった。と ころでサンバイザー試作品の中で金属板に穴の開いた素材で きたサンバイザーは他の人工皮革やモケット，織物，PVCな どとは素材の特性が大きく異なるにもかかわらず好感度が高 い.これは好感度評価以外のサンバイザーにしたときの面白 さが評価された可能性があり, 触感という観点からの好感度 評価を混乱させたと考えられる。そのため金属板からなるサ ンバイザー試作品 2 つを除いて再度相関を取り直すと $W C$ は 相関係数が-0.5（有意水準 $5 \%$ ） 以上であり，SMDは-0.44 （有意水準 $5 \%$ ）であった。一般に相関係数が-0.4〜-0.6は中 位の負の相関が有意と判断される。したがってこの結果から 触感が適度に硬く滑らかな素材が好まれ，非常に硬くてざら ざらした素材は敬遠されることが推察される。しかしこの結 果からはサンバイザーとして好まれる硬さの最適性について は不明確である。穴の開いた金属板がサンバイザーとして好 まれたのは触感とは関係なく，そのアイデアの面白さとサン バイザーを着けることによる視界が狭くなるという圧迫感を 穴が開いていることで緩和できるという心理的な要因が作用 していると考えられる。また冷温感に関して，金属板以外は 0.27 ～ 0.53 の範囲であり，人間がサンバイザーに関してはそ れほど冷温感を意識していないことが伺える。

\section{3 さまざまな材料における触感の好感度評価}

我々は好まれる素材は適度に硬くて滑らかな特性をもつか どうかを確認するために，さまざまな材料における好感度を 調査した。その結果を Table 3 に示す．好感度とは5 段階評価 の好きの度合いの平均值である。これらの力学量や冷温感を 示す $q \max$ と好感度評価である「好き」との関係を多変量解 析から導いたのが(1)式である。

\section{好き $=2.482+0.02791 L C+0.293 W C-0.264 R C$ $+0.0688 M I U-0.0966 M M D+0.0253 S M D-0.0288 q \max$}

（R:0.74, 有意水準 5\%）

これまで織物や不織布の力学量から基本風合い值 $T H V$ や 総合風合い值 $T A V$ などを算出する手法については川端，丹羽 らによる方法がある $[7,8]$. しかし今回の実験では力学量は 圧縮と表面からの7つの特性值のみで，また材料の種類も織 物から革，樹脂板，金属板，木板，ガラス，レンガなど身の 回りに存在する多種多様の材料を対象としたため，単純に 「好き」を従属変数, 各力学量と $\max$ を独立変数として EXCEL とSPSSによる多変量解析より(1)式を得た。ここでは 標準化されたデー夕について回帰分析を実施し標準化偏回帰 
係数で回帰式を導いた。実際には相関関係は 1 次式ではなく 2次式の方が精度は高くなるが，ここではあくまでも傾向を 知ることに重点を置いたので1次式での回帰近似にとどめ た。それぞれの好感度と力学量もしくは物理量を比べると WCの相関係数は+0.68，RCは-0.68，qmaxは-0.56でありこ の3つについて 0.5 以上の強い相関が認められた。硬い材料 は $W C$ が小さく逆に $R C$ が大きくて $100 \% に$ 近い材料である. またqmaxが大きいほど材料の熱伝導性がよいので触ったと きに冷たく感じる.したがって触った時に非常に硬くて冷た い材料が最も嫌われる. 逆に軟らかくて温かみのある材料と 表面の滑らかな材料が好まれる. また個々の測定パラメーター について分析してみると好感度は圧縮の $W C$ と $R C$ の值に強 く結果が影響されていることがわかった. WCの大きな材料 や RCの小さな材料が好まれるということは, 材料のヒステ リシスを人が敏感に感じていることによると思われる。すな わち指で押し込んだときにその材料の戻りの感覚が大切で戻 りの遅い材料を軟らかいと感じていると推察される。この (1)式は標準化偏回帰係数で表されているので表面特性に関 しては $M I U$ と $M M D$ で示される表面摩擦係数やその変動が好 感度に強く関係していることが伺える. その一方で表面粗さ $S M D$ と好感度の相関は低い。この理由としては人の指の感 触が幾分凹凸をもつもののほうが心地よいと感じることをあ らわしている。

式(1)から得られた「好き」の計算值と調査で得た好感度 評価の「好き」の值の相関をFig. 2に示す. この式の相関係 数 $R$ の 2 乗は 0.54 でありおおよそではあるが，さまざま材料 に対する好感度の評価に利用可能であると推察される。サン バイザー試作品では $W C, R C, S M D$ の力学量と好感度の相関が

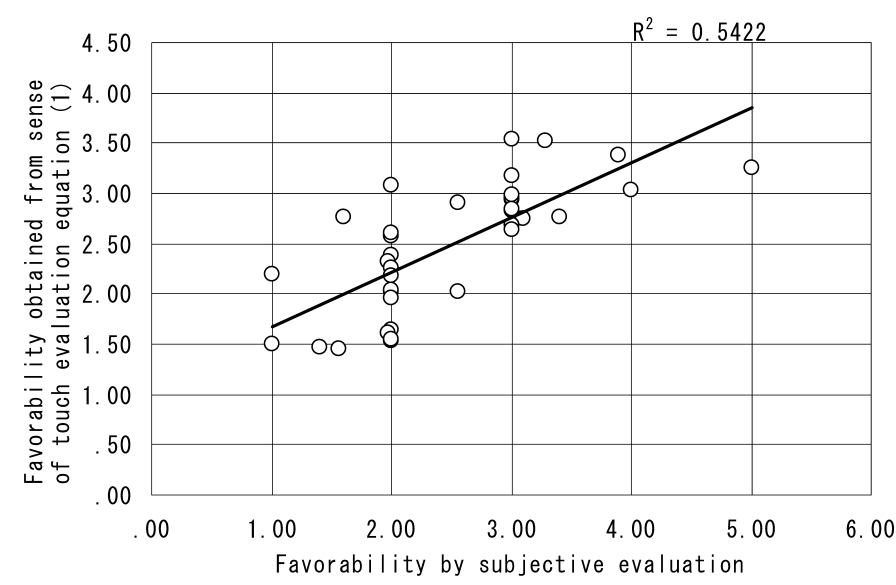

Fig. 2 Correlation of favorability of sense of touch of some materials and multiple regression equation (1) obtained from mechanical and physical quantity measurements.
高かったが，さまざまな材料では $W C, R C$ 相関が高いのは 同じであるが，さまざまな材料についての $W C$ は正の相関で あるのに対して, サンバイザー試作品での $W C$ は負の相関で

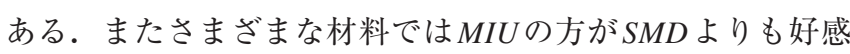
度との相関が高い結果となった. すなわちさまざまな材料で はあまりにも触感の違いが大きすぎるために(1)式がサンバ イザーとして好まれる材料を探す手段として有効かどうかは さらに検討が必要である。またこれらの材料の中で革はその 動物の種類とその部位やなめし方法などによって風合いは大 きく異なる。婦人手袋用天然革の風合いの総合評価に関して は井上ら[9]の報告があるが革の風合いの主観評価と客観評 価については今後の課題である.

\section{4. 結 論}

サンバイザーに用いられるさまざまな材料の表面特性，圧 縮特性, 冷温感特性を明らかにするために, それらの力学 量・物理量と触感の好感度との関係について検討した。 その 結果, サンバイザーとして好まれるのは革やモケットなどの 表面が非常に滑らかで適度に硬い素材のものである. 逆に嫌 われるのは非常に硬く感じる素材である．同様に一般的な材 料の触感としては, 硬くてざらざらしたものがひどく嫌われ ることが分かった. しかし素材の硬さについてはサンバイザー として好まれる最適な硬さがあり, この点についてはさらに 検討が必要である。

\section{References}

[1] Powelln B (2006) J Text Inst, 97, 25-37

[2] Krueger R (2001) Maschen Industrie, 51, 18-19

[3] Schacher L, Adolphed D (1997) World Conf Text Inst, 77th, 368-369

[4] Nishimatsu T, Hayakawa H, Shimizu Y, Kamijoh M, Toba E (1999) KANSEI Eng Int, 1, 17-24

[5] Nishimatsu T, Hayakawa H, Shimizu Y, Toba E (2000) Conf Proc IEEE Instrum Meas Technol Conf, 17th, 915-919

[6] Kawabata S (1972) Sen-i To Kogyo, 5, 277-285

[7] Kawabata S (1980) "The Standardization and Analysis of Hand Evaluation, $2^{\text {nd }}$ ed.", HESC, Text Mach Soc Japan, Osaka

[8] Kawabata S, Niwa M (1998) J Text Inst, 80, 19-50

[9] Inoue M, Matsumoto M, Nakagawa K, Andou H (2008) Abstract of The 61st Text Mach Soc Japan Annual Meeting, $224-225$ 